J. Neurol. Neurosurg. Psychiat., 1959, 22, 311

\title{
THE DIAPHRAGM IN DYSTROPHIA MYOTONICA
}

\author{
BY \\ J. E. CAUGHEY and N. PACHOMOV \\ From the Otago Medical School, Dunedin, New Zealand
}

In a previous publication, Caughey and Gray (1954) reported three patients out of 25 with dystrophia myotonica in whom the diaphragm was raised on one side. Rouques (1931) in his case records described another case but makes no comment on it. Caughey and Gray suggested that this incidence $(12 \%)$ of diaphragmatic lesions may be statistically significant and may come to be recognized as one of the variable features of the disease. Since the original report, Benaim and Worster-Drought (1954) have reported a case of dystrophia myotonica affecting both halves of the diaphragm, causing pulmonary hypoventilation with anoxaemia and secondary polycythaemia, and Bashour, Winchell, and Reddington (1955) have reported a case of dystrophia myotonica with cyanosis, polycythaemia, and unilateral elevation of the diaphragm. Recently we have had an opportunity to study two further cases of dystrophia myotonica with an elevated diaphragm, and, in one of them, to obtain a biopsy of the diaphragm. It is considered that this report is justified in view of new points which it raises.

\section{Case Reports}

Case 1.-A man, aged 62 years, a civil servant, was admitted to the Postgraduate Hospital, Hammersmith, London, under the care of Dr. Milne, who kindly referred him to me. He was well until 1953 when he began to lose weight. He was investigated at the Paddington Chest Clinic, but no abnormality of the chest was discovered and the E.S.R. was not raised.

In November, 1953, he developed an attack of right upper abdominal colic which persisted for several hours. After that attack he had a series of attacks similar in nature but varying in severity. With each he developed flatulence and anorexia and in one attack his urine became dark and he became jaundiced.

To direct questioning he stated that his neck had been weak for several years; his vision had deteriorated lately. He had not noticed any difficulty in relaxing his grip. His mother was alive and well. His father died of a stroke and one sister had had a stroke. He had had no children and his libido had failed somewhat, and apareunia had existed for four years.
On examination he was moderately well developed and well nourished. He was slightly jaundiced. The ocular fundi were normal and there were bilateral lens opacities. He had a myopathic facies with slight ptosis. There was no mechanical myotonia of the tongue. The sternomastoid muscles were almost completely wasted and the other anterior cervical muscles were wasted and weak. The upper extremities were moderately well developed. There was no wasting or weakness. There was no active or mechanical myotonia. Sensory appreciation was normal; the deep reflexes were present and equal; the abdominal muscles were not weak. There was no wasting of the lower extremities. The tone, power, and coordination were normal. There was no mechanical myotonia of the small muscles of the feet. The deep reflexes were present and equal. There was tenderness over the gall bladder region. The serum bilirubin level was $6.9 \mathrm{mg} . / 100 \mathrm{ml}$; the alkaline phosphatase 27.7 units; the van den Bergh test gave a positive direct reaction. The albumin-globulin ratio and the total protein content were normal. The prothrombin time was 30 to 45 seconds.

Radiography of the skull was normal. The chest film (Fig. 1) showed elevation of the ventral part of the right half of the diaphragm and this was confirmed by the lateral film. Paradoxical movement was seen on screening. A cholecystogram revealed stones and impaired gall bladder function.

Operation.-Professor I. Aird on May 4, 1954, performed a cholecystectomy and took biopsies from the right half of the diaphragm, the sternomastoid, and rectus muscles. Dr. Harrison reported as follows on the muscle biopsies:

Section of the rectus abdominis, diaphragm, and the sternomastoid muscles show changes which vary in degree from fairly minimal changes in the rectus to more marked disease of the diaphragm and sternomastoids. There is an abnormal variation in the size of the muscle fibres from 120 microns to grossly atrophied fibres seen in a few foci in the diaphragm, which are only a few microns across. There are areas of fibrosis in relation to atrophic fibres which may be interpreted as condensation of perimysin. There is an excess of adipose tissue, more particularly in the sternomastoid muscle where fibres are uniformly small. Occasional fibres show migration of nuclei from their usual peripheral situation to become aligned in the centre of the fibre, but this is not an outstanding feature. There is no cellular reaction or infiltration. 
Case 2.-Mr. J.B.W., aged 50 years, was first admitted to the North Canterbury Hospital in 1950 for investigation of increasing muscular weakness. The first symptom noticed by the patient was that when he tried to turn a key his right hand cramped. At the time of admission to hospital there was weakness of the legs which had been present for 10 years and difficulty in gripping objects which had been noticed for six years. The patient has not been able to support his head and could not get up from the lying position. There was also loss of libido and the patient volunteered that his voice had become "thick".

On examination he was an obese man with an expressionless face, ptosis of the eyelids, and facial weakness. Speech was slurred. There was frontal baldness but the facial hair was normal and body hair grew profusely.

The testicles were small and atrophic. Cataracts were not seen.

The apex beat of the heart was 3 in. from the midline. The heart sounds were regular but of poor quality. The pulse was 70 and blood pressure was $140 / 70 \mathrm{~mm}$. mercury. The percussion note over the chest was not impaired but a few scattered rales were heard.

There was marked weakness of the facial muscles, ptosis of the eyelids, and wasting and weakness of the sternomastoid muscles. There was wasting and weakness of the forearms and of the small muscles of the hands. The legs were also wasted and weak and there was bilateral dropfoot. There was voluntary and percussion myotonia of the hands. The deep reflexes were all absent and the plantar responses were flexor in type and the abdominal reflexes were brisk. No other abnormality was found in the central nervous system.

Special Investigation.-A lumbar puncture showed a clear fluid and the pressure was $150 \mathrm{~mm}$. of water. The Queckenstedt test was normal; the Pandy reaction was $1+$ and the protein $60 \mathrm{mg}$. per $100 \mathrm{ml}$. The Wassermann reaction was negative. The patient was treated with vitamin $\mathrm{E}$ and discharged home. Two years later diabetes was diagnosed. The patient was again in hospital four years after the original admission on account of uncontrolled diabetes mellitus. At that time his physical condition deteriorated. Radiographs of the chest revealed localized elevation of the anterior portion of the right diaphragm and a radiograph of the skull showed generalized thickness of the calvarium, large sinuses, and a small pituitary fossa. The fasting blood sugar was $333 \mathrm{mg}$. per $100 \mathrm{ml}$. and there was a lenticular opacity on the right. From that time the patient's condition deteriorated steadily and he died at the age of 56 years. There was no necropsy.

The cases previously reported are summarized in Table I together with the present cases.

\section{Discussion}

We have found few references to involvement of the diaphragm in the same pathological process as the skeletal muscles in patients with dystrophia myotonica. Sekiya (1940) points out that in a case of myopathy the diaphragm is involved late.

TABLE I

CLINICAL FINDINGS

\begin{tabular}{|c|c|c|c|c|c|c|c|c|c|c|c|c|c|}
\hline \multirow[b]{2}{*}{$\begin{array}{l}\text { Case and } \\
\text { Author }\end{array}$} & \multirow[b]{2}{*}{$\begin{array}{l}\text { Sex } \\
\text { and } \\
\text { Age } \\
\text { (yr.) }\end{array}$} & \multirow[b]{2}{*}{$\begin{array}{l}\text { Family } \\
\text { History }\end{array}$} & \multirow[b]{2}{*}{ Cataract } & \multicolumn{3}{|c|}{ Myotonia } & \multicolumn{3}{|c|}{ Wasting } & \multicolumn{3}{|c|}{ Skull } & \multirow[b]{2}{*}{ Diaphragm } \\
\hline & & & & 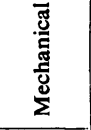 & $\sum_{\substack{0\\
}}^{0}$ & $\begin{array}{l}8 \\
\text { : } \\
\end{array}$ & 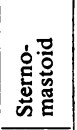 & $\frac{E}{<}$ & $\stackrel{\infty}{\Xi}$ & 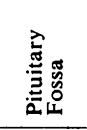 & 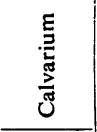 & 安育 & \\
\hline $\begin{array}{l}\text { 1. G.L. } \\
\text { Caughey and } \\
\text { Gray }\end{array}$ & $\begin{array}{l}\mathbf{M} \\
\mathbf{5 0}\end{array}$ & Negative & $\begin{array}{l}\text { Posterior } \\
\text { polar }\end{array}$ & $\begin{array}{l}\text { Hands } \\
\text { and } \\
\text { tongue }\end{array}$ & Grip & + & + & + & + & Small & Thick & No & $\begin{array}{l}\text { R. side elevated. } \\
\text { Very slight respira- } \\
\text { tory excursion }\end{array}$ \\
\hline 2. E.W. & $\begin{array}{l}F \\
40\end{array}$ & Positive & Bilateral & $\begin{array}{l}\text { Tongue } \\
\text { and }\end{array}$ & Grip & ++ & ++ & ++ & ++ & $\begin{array}{l}\text { Very } \\
\text { small }\end{array}$ & +++ & ++ & $\begin{array}{l}\text { Left side elevated, } \\
\text { immobile }\end{array}$ \\
\hline $\begin{array}{l}\text { 3. E.H. } \\
\text { Caughey and } \\
\text { Gray }\end{array}$ & $\underset{55}{F}$ & $?$ & $\begin{array}{l}\text { Bilateral } \\
\text { cataracts }\end{array}$ & Nil & Nil & + & +++ & +++ & - & $\begin{array}{l}\text { Small } \\
\text { to } \\
\text { normal }\end{array}$ & +++ & ++ & $\begin{array}{l}\text { Right side elevated; } \\
\text { excursion, } \\
\text { R. } 1 \mathrm{~cm} . \text { L. } 4 \mathrm{~cm} .\end{array}$ \\
\hline Rouques Case & $\begin{array}{l}\mathbf{M} \\
\mathbf{3 8}\end{array}$ & Positive & $\begin{array}{l}\text { Bilateral } \\
\text { cataracts }\end{array}$ & Yes & Grip & + & +++ & + & + & Small & - & $+t$ & $\begin{array}{l}\text { Left side inner half. } \\
\text { Costophrenic angle } \\
\text { is obliterated on }\end{array}$ \\
\hline $\begin{array}{l}\text { 5. S.G. } \\
\text { Benaim and } \\
\text { Worster- } \\
\text { Drought }\end{array}$ & $\begin{array}{l}\mathbf{M} \\
\mathbf{3 8}\end{array}$ & $\begin{array}{l}\text { Parents } \\
\text { had } \\
\text { cataracts }\end{array}$ & $\begin{array}{l}\text { Bilateral } \\
\text { polar } \\
\text { cataracts }\end{array}$ & $\begin{array}{l}\text { Hands } \\
\text { and } \\
\text { tongue }\end{array}$ & +++ & Nil & +++ & +++ & ++ & Normal & Normal & Normal & $\begin{array}{l}\text { the left } \\
\text { Bilateral elevation } \\
\text { of diaphragm }\end{array}$ \\
\hline $\begin{array}{l}\text { 6. F. } \\
\text { Bashour }\end{array}$ & $\begin{array}{l}\mathbf{M} \\
\mathbf{5 7}\end{array}$ & $\begin{array}{l}\text { Father } \\
1 \text { brother } \\
1 \text { sister }\end{array}$ & $\begin{array}{l}\text { Bilateral } \\
\text { cataracts }\end{array}$ & $\begin{array}{l}\text { Not } \\
\text { re- } \\
\text { corded }\end{array}$ & $\begin{array}{c}\text { Not } \\
\text { re- } \\
\text { corded }\end{array}$ & + & +++ & $+t$ & $t+$ & - & - & - & $\begin{array}{l}\text { Elevation right leaf } \\
\text { of diaphragm with } \\
\text { restricted move- } \\
\text { ment of the entire }\end{array}$ \\
\hline $\begin{array}{l}\text { 7. M.C. } \\
\text { Present case }\end{array}$ & $\begin{array}{l}\mathbf{M} \\
\mathbf{6 2}\end{array}$ & Nil & $\begin{array}{l}\text { Bilateral } \\
\text { cataracts }\end{array}$ & Nil & Nil & + & $++t$ & - & - & Normal & Normal & Normal & $\begin{array}{l}\text { Elevation of ventral } \\
\text { portion of } R \text {. dia- } \\
\text { phragm. Para- } \\
\text { doxical movement } \\
\text { of the diaphragm }\end{array}$ \\
\hline $\begin{array}{l}\text { 8. J.B.W. } \\
\text { Present case }\end{array}$ & $\begin{array}{l}\mathbf{M} \\
\mathbf{5 0}\end{array}$ & $\begin{array}{l}\text { Father } \\
\text { had } \\
\text { myotonia }\end{array}$ & R. eye & Yes & Yes & + & ++ & + & + & Small & Thick & - & $\begin{array}{l}\text { Elevation sternal } \\
\text { portion of right } \\
\text { diaphragm }\end{array}$ \\
\hline
\end{tabular}


Robinson, Mosberg, and Lowe (1950) made a study of diaphragmatic movements in various neurological disorders and investigated a group of six patients with unspecified muscular disorders where there was marked wasting of the shoulder girdle muscles but no change in the diaphragmatic movement. Benaim and Worster-Drought (1954) were able to demonstrate electromyographically myotonia of the intercostal muscles, but were unable to take electromyograms from the diaphragm. The severity of myotonia was such as to interfere with respiration and caused severe anoxia due to hypoventilation. Bashour et al. (1955), reporting on a case of dystrophia myotonica, described right-sided elevation of the diaphragm, also cyanosis, polycythaemia, greatly decreased vital capacity, and increased pressure in the pulmonary artery $(38 \mathrm{~mm}$.), and presumed that decreased movement of the respiratory muscles was the cause of the hypoventilation.

In the initial publication Caughey and Gray (1954) reported unilateral elevation of the diaphragm in three cases. Subsequently Benaim and WorsterDrought (1954) reported a case with both halves of the diaphragm affected. The two cases reported here are of interest on account of the partial elevation of one half of the diaphragm. It appears to be the sternal portion of the right diaphragm which is involved in both cases. Thus it appears that in dystrophia myotonica we may have involvement of both halves of the diaphragm, half the diaphragm, or a portion only of one half.

In a previous publication one of us (J.E.C.) was unable to observe under the $x$-ray screen delayed relaxation of the diaphragm to command. In the first of the two cases reported here, we were able to obtain biopsies of the various muscles, including the diaphragm. The sternomastoid muscle was severely involved in the atrophic process and the diaphragmatic muscle showed localized, but definite changes such as variation in the size of the muscle fibres, increase of connective and fatty tissue, and formation of central chains of nuclei. This report presents definite evidence that the diaphragm also might be involved in the same dystrophic process as other skeletal muscles but probably late in the disease process.

Black and Ravin (1947), in their report on the necropsies of five cases of dystrophia myotonica, were unable to find definite abnormal changes in the diaphragm. In the differential diagnosis, lesions of the spinal cord or phrenic nerve could be excluded. Eventration is a congenital lesion and always occurs on the left side, and in cases of left-sided elevation of the diaphragm should be seriously considered, as it might be one of the congenital abnormalities present in a case of dystrophia myotonica.

As previously suggested we are of the opinion that elevation of the diaphragm should come to be accepted as one of the variable features of dystrophia myotonica.

\section{Summary}

Two cases of dystrophia myotonica with rightsided elevation of the diaphragm are reported.

In one case biopsy of the diaphragmatic muscle showed definite histological changes of a muscle dystrophy.

Elevation of the diaphragm may be partial, unilateral, or bilateral, and should come to be accepted as a variable feature of dystrophia myotonica.

We are grateful to Dr. Milne, of the Postgraduate Hospital, Hammersmith, who referred Case 1, and to Dr. Cunningham, of the North Canterbury Hospital, who gave us access to the second case. We are grateful for secretarial assistance from Mrs. G. Sim and Mrs. J. Pilkington.

\section{REFERENCES}

Bashour, F. Winchell, P., and Reddington, J. (1955). New Engl. J. Med., 252, 768.

Benaim, S., and Worster-Drought, C. (1954). Med. Ill., 8, 221.

Black, W. C., and Ravin, A. (1947). Arch. Path. (Chicago), 44, 176 Caughey, J. E., and Gray, W. G. (1954). Thorax, 9, 67.

Robinson, P. K., Mosberg, W. H., and Lowe, R. C. W. (1950) J. Neurol. Neurosurg., Psychiat., 13, 296.

Rouques, L. (1931). La Myotonie Atrophique, p. 40. Legrand,

Sekiya, M. (1940). Orient. J. Dis. Infants, 28, 8. 